\title{
Understanding the Qur'anic Miracle Stories in the Modern Age
}

\author{
Isra Yazicioglu \\ University Park: The Pennsylvania State University \\ Press, 2013. 176 pages.
}

In the introduction to her Understanding the Qur'anic Miracle Stories in the Modern Age, Isra Yazicioglu writes about the dilemma of how readers are to understand such stories. She poses the question that if both the Qur'an and scholars of Islamic thought argue that Muhammad's message is his miracle (p. 5) and that natural phenomena contain miracles, then why is there a need for such narrations? And since they are only narrations of miracles, for readers do not actually witness these miracles, do they "count as evidence of God's power?" (p. 8). Stemming from these and other related questions, much of the book revolves around issues of causation and sources of knowledge. This book will appeal to advanced university students and academics interested in Qur'anic studies and especially in Islamic philosophy.

Part I, "Medieval Muslim Debate," includes a chapter on al-Ghazali and Ibn Rushd. Each chapter includes a welcome biographical section on the scholar under discussion. Starting with al-Ghazali, we see the idea that God can and has sent miracles to verify His messengers and that this is fundamental in Islam (p. 18). These miracles enable people to discern between prophets and imposters (p. 19) and by creating miracles God "nonverbally 
confirms a prophet's claim" (p. 20). Still, the message must make sense for the miracle to count as evidence (p. 21). From here, we move on to discussions of natural causation and that although we may normally observe a natural cause to have a particular effect, having one but not the other can be logically sound (p. 30). Thus, Abraham can be thrown into a fire and not burn (p. 30). While there is a "'habitual' execution of the acts of creation" and thus "order in the universe and ... predictability of future events," this does not necessitate causation between events (p. 35). Thus, "to accept the possibility of miracles is to accept that the natural order is not a logical given but a gift' (p. 41).

Chapter 2 brings us to Ibn Rushd and a discussion of who can interpret which types of Qur'anic verses in what ways - literally or metaphorically, by rhetorical means ("common people"), dialectical (theologians), or demonstrative (philosophers) (pp. 47-49). He asserts causation and that to deny it is to deny the certainty of knowledge (p. 57). For him, miracles are not proof of prophecy; the message is the real proof.

Part II, "Reframing the Debate on Miracles in Modern Terms," contains chapters on David Hume (1711-76) and Charles S. Peirce (1839-1914). In chapter 3, we read about Hume and his argument that experience is the "most important source of knowledge" (p. 73). Yazicioglu points out places in which his thoughts resemble those of al-Ghazali (e.g., 77, 79). However, Hume insists that miracle reports not be believed, especially if they come with religious claims (p. 88). Peirce, who is featured in chapter 4, rejects claims of universal doubt and "affirms ... that reason[,] ... instincts and habits play an indispensible role in acquiring knowledge" (p. 95). He believes that "empirical conclusions are never absolute" (p. 104). Thus, "miracle stories signify the presence of indeterminacy in nature, and encourage us to keep the road of inquiry open for new discoveries and possibilities" (p. 119).

Finally, Part III, "Contemporary Connections," has a chapter on Said Nursi (1877-1960). Yazicioglu writes about his approach to Qur'anic hermeneutics, which contains four elements as regards interpretation: the speaker, audience, purpose, and context (p. 130). About miracles, Nursi emphasizes that the Qur'an presents ordinary phenomena as miracles despite the fact that they are "often overlooked simply because of [their] familiarity" and "Nursi regards a miracle as anything that natural causes are incapable of producing" (p. 135). Yazicioglu explains that Nursi bridges some of the different perspectives of Ibn Rushd and al-Ghazali (pp. 141, 144). Causal thinking can actually lead us to acknowledge divine agency, the "causer of causes" (p. 142). When it comes to Qur'anic miracles, such as Abraham not burning in the fire, this "teaches the reader that fire burning in everyday life is not a simple event. 
Rather it is an event that requires no less than the agency of an all-powerful One" (p. 147). Miracle stories can give inspiration for scientific and technological discoveries (pp. 155-56), an understanding that reflects an "attempt on the part of a believer to read the Qur' an as speaking to his contemporary context" (p. 157). In the end, with the "overall purposes of the Qur'an in mind, the miracle stories ... enhance the overall Qur' anic emphasis on nature by interrupting our familiarity with it" (pp. 162-63).

In the conclusion, "Qur'anic Hermeneutics in the Modern Age," Yazicioglu mentions how she brought up a classical Muslim philosophical debate and discussed it with modern philosophical ones (p. 167). This is certainly a strength of her book. She brings together various thinkers and ways of thinking during her discussion of the philosophical issue of miracles. She concludes that although miracles initially appear to show a contradiction between science and scripture, this can be resolved by seeing the connection between the two, that "nature, as well as our familiarity with it, [is] a gift" (p. 169). She writes about the pragmatic interpretation of the Qur'an (pp. 173-74) and reading the text with attention to its implications (p. 176). There is little analysis of the Qur'anic miracle stories in the book - the way they are told, or their history of interpretation. More than anything else, these stories are a starting point of inquiry. This book is really about the issue of miracles and the philosophical issues related to them - free will, causality, and knowledge. This contribution to the field of Islamic philosophy should be of great interest to those interested in it and the intersections between that particular field and the Qur'an.

Note: This activity has been partially funded by a grant from the Sultan Program of the Center for Middle Eastern Studies, University of California, Berkeley.

Leyla Ozgur Alhassen 